\section{Polycyclic Aromatics via Cross-Coupling}

Key words

cross-coupling

polycyclic aromatics<smiles>CC1(C)OB(C([Al])=C(Br)B2OC(C)(C)C(C)(C)O2)OC1(C)C</smiles><smiles>BrC1=C(Br)C2CC1C1CCCC21</smiles>

$\mathrm{Pd}\left(\mathrm{PPh}_{3}\right)_{4}(5 \mathrm{~mol} \%)$

$\mathrm{K}_{2} \mathrm{CO}_{3}$ (6 equiv)

$\mathrm{H}_{2} \mathrm{O}$ (50 equiv), THF, $60{ }^{\circ} \mathrm{C}$

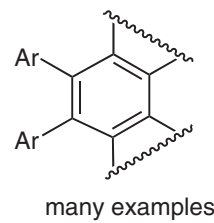

organic

semiconductors

SYNFACTDath<smiles>CC1(C)OB(C(=C[PH2+])c2ccccc2-c2ccccc2-c2ccccc2Br)OC1(C)C</smiles><smiles>Pc1ccccc1-c1ccccc1</smiles>

$\mathrm{R}=\mathrm{Me}, 85 \%$
$\mathrm{R}=\mathrm{OMe}, 82 \%$

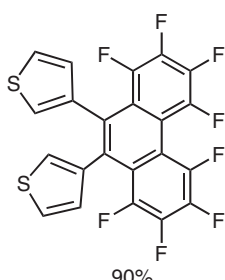

$90 \%$<smiles>Fc1c(F)c(F)c2c(-c3ccccc3)c(F)c(F)c(F)c2c1F</smiles>

$65 \%$<smiles></smiles>

$32 \%$<smiles>c1ccc(-c2c(-c3ccccc3)c3sccc3c3ccsc23)cc1</smiles>
$4 \%$<smiles></smiles>

$57 \%$

Significance: This report demonstrates a powerful method for the formation of functional polycyclic aromatic structures. These classes of structures are important building blocks for the formation of organic semiconductor materials. The high yields of the reactions suggest a practical method to produce quantities of materials and the (Z)-1,2-bis(pinacolatoboryl)stilbenes and related compounds are readily prepared from the biboryl and diarylalkynes (J. Chem. Soc., Dalton Trans. 2001, 1650).
Comment: Few cross-coupling reactions directly give new aromatic ring systems. The ability to incorporate both electron-rich (thiophene) and electron-poor (perfluoroaromatic) groups into the final products makes this method useful for the synthesis of a variety of useful organic semiconductors. The higher reactivity of the vicinal boryl groups is noteworthy and likely contributes to the ability to produce strained helicenes. 